\title{
1990-91 Annual Report
}

\section{Association Of}

C OLLEGE

\& RESEARCH

LIBRARIES

A D I V I S I O N O F T H E

AMERICAN LIBRARY ASSOCIATION

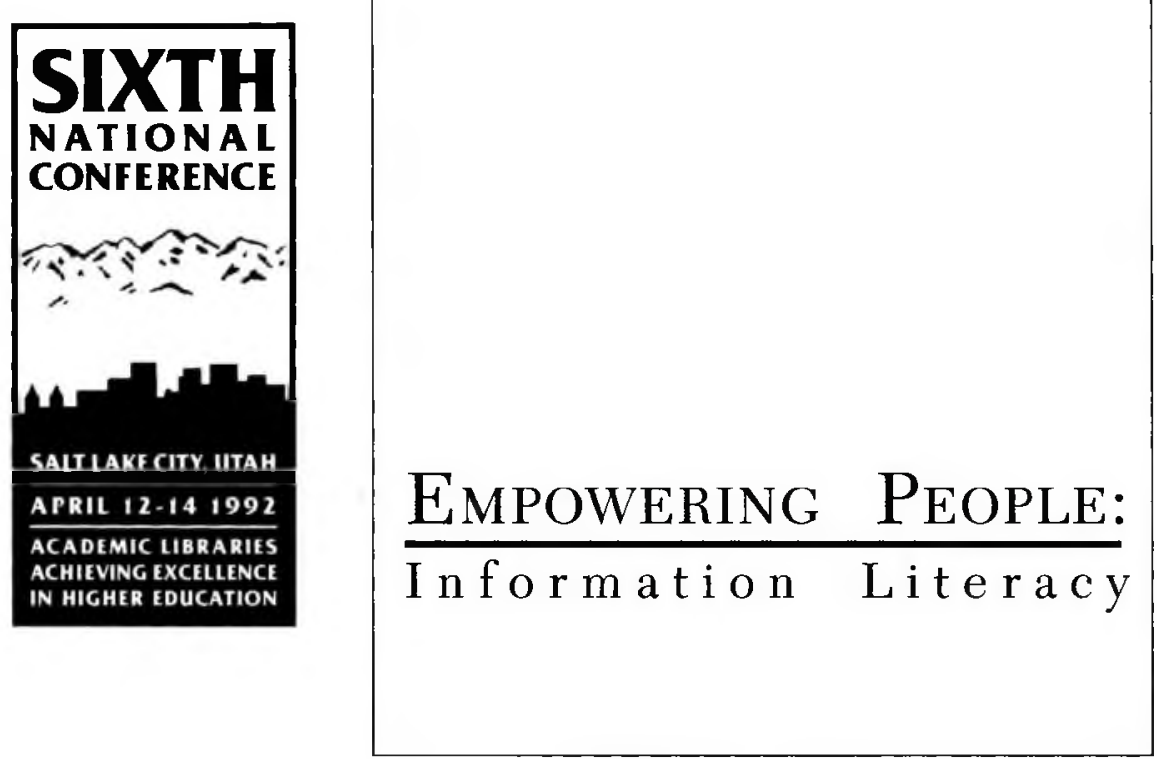




\section{Mission}

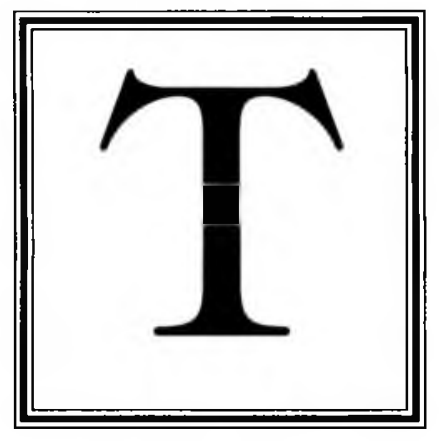

he mission of the Association of College and Research

Libraries (ACRL) is to foster the profession of academic and research librarianship and to enhance the ability of academic and research libraries to serve effectively the library and information needs of current and potential library users. 


\title{
Message from the President
}

\author{
BARBARA J. FORD \\ ACRL'S 52ND PRESIDENT
}

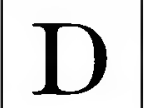

uring the past year, along with many other activities, ACRL took a leadership role in promoting information literacy. In the midst of the information explosion, the

ability to find, evaluate, and use information is an important part of a definition of literacy. To be fully literate one should know when information is needed and be able to locate, evaluate, and use information for problem-solving and decisionmaking. Libraries provide a model for the information environment in which people work and live and librarians can help users master these critical skills.

Throughout the year we published articles on information literacy in College $\mathcal{E}$ Research Libraries News and identified individuals who can serve as advisers to academic librarians working on information literacy. We developed posters, pamphlets, folders, and even a flying disc that can be

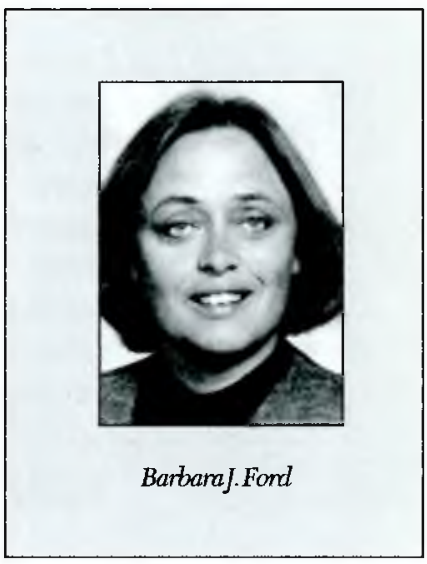
used to spread the word about information literacy in a variety of campus environments. I made presentations about information literacy at ACRL chapter meetings throughout the United States.

The ACRL program planning committee presented a very successful program on information literacy at the Annual Conference in Atlanta. Moon Unit Zappa and Patricia Senn Breivik made interesting presentations at a program attended by a variety of ALA members. The poster sessions developed by ACRL members for the program provided excellent examples of successful information literacy programs at a number of colleges and universities.

ACRL joined approximately 50 educational organizations affiliated with the National Forum on Information Literacy. We will continue working with the Forum to promote and expand programs relating to information literacy. One recommendation from the White House Conference on Library and Information Services calls for the president and Congress to establish a Na- 


\section{Message from the President}

tional Coalition for Information Literacy. The Coalition will develop a strategic plan for the general development of information literacy skills. Such a coalition would include schools, libraries, government, labor and industry, parents, and the public at large. Much still remains to be done as we continue to work with other sectors of the education community to expand and develop programs relating to information literacy. Join us as we build on the activities of the past year and continue promoting information literacy.

I have found it rewarding and stimulating to be ACRL's president and to work with so many talented and enthusiastic academic and research librarians. I wish to thank the many individuals who helped make my presidency such a positive experience. The association staff is excellent and without them the many important ACRL activities could not continue. Members and staff working together have contributed their time and energies to making ACRL a very successful organization. It has been an honor and a pleasure to work with you as president.

\begin{tabular}{|c|c|c|c|c|c|c|}
\hline \multicolumn{7}{|c|}{ ACRL MEMBERSHIP STATISTICS } \\
\hline $\begin{array}{l}\text { ACRU } \\
\text { Sections }\end{array}$ & Personal & Organization & Special & $\begin{array}{l}\text { Aug. } 1991 \\
\text { Total }\end{array}$ & $\begin{array}{l}\text { Aug. } 1990 \\
\text { Totals }\end{array}$ & $\begin{array}{l}\text { \%increase } \\
\text { decrease }\end{array}$ \\
\hline ACRL & 9,534 & 1,116 & 43 & 10693 & 10639 & $.5 \%$ \\
\hline AAS & 402 & 83 & 1 & 486 & 482 & $.8 \%$ \\
\hline AFAS & 178 & 13 & 2 & 193 & 0 & \\
\hline ANSS & 484 & 96 & 1 & 581 & 596 & $-2.5 \%$ \\
\hline ARTS & 763 & 117 & 7 & 887 & 862 & $2.9 \%$ \\
\hline BIS & 3,681 & 483 & 5 & 4,169 & 4,072 & $2.3 \%$ \\
\hline CJCLS & 826 & 262 & 11 & 1,099 & 1,100 & $-0.9 \%$ \\
\hline CLS & 1,832 & 356 & 20 & 2,208 & 2,177 & $1.4 \%$ \\
\hline EBSS & 1,298 & 229 & 8 & 1,535 & 1,583 & $-3.1 \%$ \\
\hline ECLSS & 230 & 13 & 0 & 243 & 3 & $8,000 \%$ \\
\hline LPSS & 748 & 118 & 5 & 871 & 888 & $-1.9 \%$ \\
\hline \begin{tabular}{|l|} 
RBMS \\
\end{tabular} & 1,736 & 215 & 4 & 1,955 & 1,995 & $-2 \%$ \\
\hline SEES & 248 & 65 & 2 & 315 & 308 & $2.2 \%$ \\
\hline STS & 1,602 & 262 & 12 & 1,876 & 1,926 & -2.6 \\
\hline ULS & 5,972 & 373 & 27 & 6,372 & 6,443 & $1.1 \%$ \\
\hline WESS & 728 & 67 & 4 & 799 & 789 & $1.2 \%$ \\
\hline WSS & 778 & 68 & 33 & 849 & 801 & $5.9 \%$ \\
\hline
\end{tabular}




\title{
Message from the Vice-President
}

\author{
Anne K. Beaubien \\ Vice-President / President-Elect
}

\section{M}

$y$ theme for ACRL during 1991-92 is recruiting talented

people to the profession. According to research and to

the experience of library personnel managers, there is

a severe and chronic shortage of applicants for professional positions who have solid training in the sciences and social sciences or who come from racially or ethnically diverse backgrounds. One reason our field is not attracting people with these qualifications is the persistent erroneous stereotype of who we are and what we do. We all have welleducated acquaintances who do not have the faintest idea of how varied and challenging our work is or the extent of our responsibilities. This ignorance has, I believe, a direct and negative impact on our profession: talented individuals do not consider librarianship as a career, let alone the many other areas of information science, because they do not see us in action over time. I want to devote my year as president of ACRL to changing this situation.

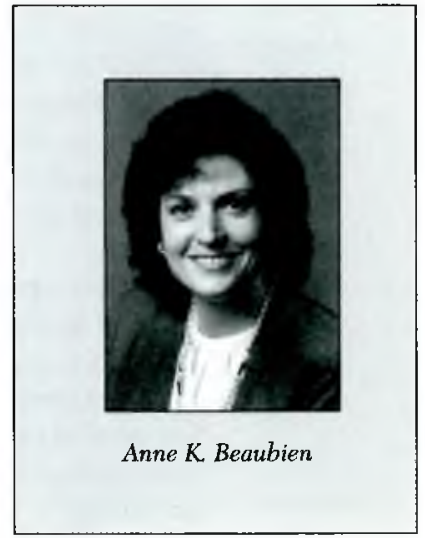

One way I hope to promote a clearer awareness of our abilities is by updating the librarian profiles used by major career aptitude tests. The producers of both the Strong Interest Inventory and the SIGI PLUS career guidance program on CD-ROM have indicated they would welcome advice from ACRL about their respective profiles for librarianship. Over the next few months Mary Jane Scherdin of the University of Wisconsin will be conducting research, funded in part by ACRL, to correlate the interests and personality characteristics of experienced librarians with the items found on standard tests. Dr. Scherdin will also chair the ACRL Task Force on Vocational Interest Inventories that I have established.

ACRL is fortunate that the ALA minority intern, Sheila Delacroix, has chosen her assignment in ACRL. I will be working with her during the year on an array of recruitment activities. Pamela Cravey of Georgia State University will chair the newly formed ACRL Task Force on Image to look at recruitment issues from the sensitive angle of how we present ourselves profession- 


\section{Message from the Vice-President}

ally and how we are portrayed by others. My presidential program next June 29 during ALA in San Francisco will provide ACRL members with the chance to share ideas about recruitment with key people in four areas: college career counselors, librarians active in successful statewide recruitment networks, faculty who make library school admission decisions, and academic and research library personnel officers. Other projects I am initiating are the creation of a recruitment brochure, several grant applications with recruitment as a focus, and a series of articles on that topic in CERL News. I have also collaborated with Margaret Myers of ALA's Office for Library Personnel Resources to submit a proposal for a workshop focusing on the library and information science profession. If the proposal is approved, the workshop would take place in March 1992, prior to the convention of the American Association for Counseling and Development in Baltimore.

Recruitment of talented people to the profession relates directly to Patricia Schuman's theme as ALA President, "Your Right to Know." Society's obligation to provide timely, accurate information on all subjects to all citizens requires an ever-expanding pool of excellent professionals from all personal and intellectual backgrounds. Recruitment was also a top priority issue according to the most recent ACRL membership survey.

Those are my activities to date as ACRL vice-president and now president. I welcome reactions to them and would like to hear suggestions of other ways to implement my theme. Please contact me directly at the University of Michigan Library or send your ideas to Mary George at Princeton University who chairs my Program Planning Committee. Our recruiting efforts of today will yield the colleagues and leaders we will admire tomorrow. I am eager to think and work with you toward that end throughout the coming year. 


\section{Letter from the \\ Acting Executive Director}

\section{Cathleen Bourdon \\ ACTING ExeCUTIVE DiReCTOR}

$\mathbf{L}$ ast year provided many challenges for academic librarians and ACRL. As the effects of the recession were felt in each state, higher education learned to do with less.

Academic librarians, always resourceful in lean as well as flush times, struggled with the challenges of job freezes, cutbacks, and budget reductions. ACRL shared this challenge with you as we faced many of the same problems. Our success in meeting these challenges is due to the continuing strength, loyalty, and commitment of our nearly 11,000 members.

Led by your elected representatives, ACRL affirmed the importance of holding national conferences and moved the conference from Phoenix to Salt Lake City (see April CERL News, p. 254). Scheduled for April 12-14, 1992, the ACRL Sixth National Conference will present over 90 programs on bibliographic instruction, collection management and control, reader services, technology,

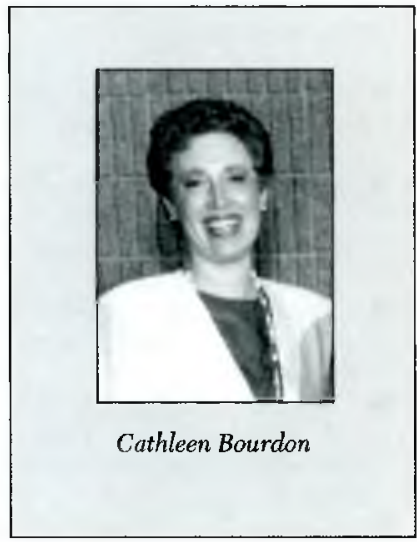
cultural diversity, personnel management, and library administration. The ACRL National Conference is the only national conference just for you and I hope you will join your colleagues there. The preliminary program and registration materials will be mailed to you in November. Three major association activities came to a close in 1990-91. The Historically Black College and University Library Project, funded in part by a grant from the Mellon Foundation, completed its final year with an accreditation workshop and a statistics project. The Alternative Sources of Revenue for Academic Libraries Project, funded by H.W. Wilson Foundation and directed by the ALA Office for Research, issued its final report. The ACRL Task Force on the White House Conference advanced the concerns of academic librarians at the July conference. Although the White House Conference is over, the ACRL Task Force will continue its efforts in 1991-92 to implement the resolutions of interest to academic librarians.

Six continuing education courses and approximately 11 local courses were provided to our membership through ACRL chapters and individual libraries. 


\section{Letter from the \\ Acting Executive Director}

The year brought a number of staff changes. Althea $\mathrm{H}$. Jenkins, formerly the library director at the Sarasota/New College Campus of the University of South Florida, became the ACRL executive director in July. Mary Ellen Davis was named the editor/

\section{ACRL Staff}

Call us toll free at 1-800-545-2433 ext. XXXX or call us direct at (312)-280-XXXX.

- Althea H. Jenkins (start date July 1, 1991), Executive Director - 3248

- Cathleen Bourdon, Acting Executive Director (FY90-91); Deputy Executive Director 2517

- Mary Ellen K. Davis, Editor $\mathcal{E}$ Publisher, C\&RL News 2511

- Mary C. Taylor (start date July 1, 1991), Program Officer, Publications/Standards/Statistics - 2515

- Carolyn R. De Bonnett, Program Assistant, Membership/ Chapter Relations - 2510

- Pam Spiegel, Assistant Editor, C\&RL News - 2524

- Ted Bales, Classified Ads Manager, C\&RL News - 2513

- Reginald Prim, Editorial As sistant, C\&RL News - 2514

- Patrick Jeanty, Administrative Secretary - 2525

- Cynthia Taylor, Administrative Secretary - 2521

- Beverley M. Washington, Administrative Assistant - 2516

- Patricia Sabosik, Editor/Publisher, Choice, 100 Riverview Center, Middletown, CT 06457, (203) 347-6933

Association of College and Research Libraries ( $A C R L$ ), A Division of the American Library Association, 50 East Huron St.,Chicago, IL 60611-2795 publisher of $C \mathcal{E} R L$ News in February, after serving for six years as ACRL's director of communications and systems. She replaced George $M$. Eberhart, who left in September. Carolyn R. De Bonnett became the program assistant for membership and chapters in October, succeeding Alia Al-Taqi. Carolyn previously served as the administrative assistant to the ACRL executive director. Mary Taylor, formerly the communications and information services manager at OCLC's Office of Research, joined the ACRL staff in July as the ACRL publications program officer. In June, Pam Spiegel became the assistant editor, and Ted Bales the classified ads manager for CERL News, sharing the job last held by Karen Christopher. We said goodbye to Mattye L. Nelson, formerly education officer for ACRL, as she took up her new duties as the director of the ALA Office for Library Outreach Services in July.

Although the year was a challenging one, I enjoyed the opportunity to serve as the ACRL acting executive director. Thanks to your continued support, ACRL will continue to be a strong partner in higher education. 


\section{The Year in Review}

Goal 1.

Professional Development.
Contribute to THE TOTAL PROFESSIONAL DEVELOPMENT OF ACADEMIC AND RESEARCH LIBRARIANS.

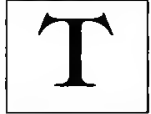

he Canadian Studies Discussion Group (Brian Coutts, chair) hosted a special session on Canadian periodical and newspaper indexing.

The University Libraries Section (ULS) (Janice Koyama, chair) formed a new discussion group for academic librarians involved in higher education administration.

The Education and Behavioral Sciences Section (EBSS) (Tara Lynn Fulton, chair) Current Topics Discussion Group and the Social Work/ Social Welfare Committee each met for the first time at midyear.

The Personnel Administrators and Staff Development Officers Discussion Group (Maidel K. Cason and Marilyn H. Shaver, co-chairs) met a total of seven times during the year to discuss personnel and staff development issues.

A new task force was established on professional development (Meredith Butler, chair) to take a fresh look at providing continuing education. While this investigation is underway the $\mathrm{CE}$ courses will not be offered by ACRL in conjunction with Annual Conference.

The Heads of Reader/Public Services Discussion Group (Sylverna Ford, chair) sponsored a meeting focused on goal setting for public services.

The Western European Specialists Section (WESS) (Eva Sartori, chair) has created two discussion groups: the Scandinavian Discussion Group and the Romance Languages Discussion Group.

The College Libraries Section (CLS) (Michael D. Kathman, chair) established a framework and developed a grant proposal for a mentoring program for new library directors.

The Extended Campus Library Services Section (ECLSS) (Barton M. Lessin, chair) has uti-

\section{SECTION \\ PROGRAMS}

- Afro-American Studies Librarian (AFAS)

"Information Literacy: Black Families \& Literacy"

- Anthropology and Sociology (ANSS)

"Folk Cultures of the Modern South: Documentation of Living Traditions"

- Arts (ARTS)

"Becoming Literate with Our Heritage: The WPA and the Arts"

- Asianand African (AAS) "Information Literacy Issues in the African \& Asian Context"

- BibliographicInstruction (BIS)

"Technology as a Barrier to Information Literacy: Implication for Bibliographic Instruction Programming"

- College Libraries (CLS) "Staff Development in Small $\&$ Medium-Sized Libraries"

- Community and Junior College Libraries (CJCLS)

"Empowering Students: Institutionalizing Information Literacy in Higher Education" 


\section{The Year in Review}

lized its first year to establish a foundation for successful growth, programming, and information sharing.

The Publications Committee (Pamela Snelson, chair) estab-

Programs (cont.)

- Education and Behavioral Sciences (EBSS)

"Teaching Study Skills: The High School to College Experience"

- Law and Political Sciences (LPSS)

"Empowering the Public: Information Literacy for Environmental Issues"

- Rare Books and Manuscripts (RBMS)

"Scholarly Editing Projects in Libraries"

- Science and Technology (STS)

"Promoting Scientific Literacy $\mathcal{E}$ Education: Can Libraries Meet the Challenge?"

- Slavic and East European (SEES)

"Perestroika, Glasnost $\mathcal{E}$ the Library World"

- University Libraries(ULS) "Libraries on the Shores of Lake Atlantic: Diverse Approaches - Common Issues"

- Western European Specialists (WESS)

"European Unification 1992: Impact on Information \& Libraries"

- Women's Studies (WSS)

"Women's Studies \& Ethnic Diversity: Transforming Competition into Coalition" lished an ad hoc task force to review section newsletters.

The Research Committee (Charles T. Townley, chair) initiated a pilot project linking beginning researchers with mentors through BITNET.

Three preconferences were offered: "Preparing for Professional Education and Regional Accreditation" sponsored by the Historically Black College \& University Project Planning Committee (HBCU) (Beverly P. Lynch, chair); "Cultural Diversity \& Higher Education" sponsored by the Bibliographic Instruction Section (BIS) (Betsy Wilson, chair); "Keeping the Facts in Artifacts: Conserving the Physical Evidence of Special Collections Materials and Its Impact on Research" sponsored by the Rare Books and Manuscripts Section (RBMS) (Daniel H. Traister, chair). 


\section{The Year in Review}

GoAL 2.

\section{ENHANCING}

Service Capability.
ENHANCE THE CAPABILITY OF

ACADEMIC AND RESEARCH LIBRAR-

IES TO SERVE THE NEEDS OF USERS.

\section{7 he Performance Measures for Academic Libraries Dis- cussion Group (Mignon Adams, chair) held its first meeting with a very inter-}

ested audience of about fifty members.

The Anthropology and Sociology Section (ANSS) (Cheryl C. Kugler, chair) initiated the Anthropology Librarians' Discussion Group to consider issues of acquiring, controlling, and/or accessing anthropological material.

The Undergraduate Librarians Discussion Group (UGLI) (Paula Walker, chair) published a statistical report on 26 undergraduate libraries in North America.

The Women'sStudies Section (WSS) (Patricia A. Kreitz, chair) held a well-attended discussion section on information literacy from a feminist perspective.

The Extended Campus Library Services Discussion Group (Virginia Witucke, chair) shared ideas for providing service to off-campus faculty.

The Western European Specialists Section (WESS) (Eva Sartori, chair) is participating in a study of acquisitions of foreign materials by U.S. libraries.

The College Libraries Section Standards Committee (David B. Walch, chair) surveyed over 300 college libraries to elicit information regarding their implementation of the 1986 Standards. A partial revision to the Standards was recommended.

The Afro-American Studies Librarians Section (AFAS) (Clarence E. Chisholm, chair) is conducting a study of indexing terms used by the

\section{AWARD WINNERS, 1991}

- Academic or Research Librarian of the Year Award (donated by Baker E Taylor Books)

Richard De Gennaro, the Roy E. Larsen Librarian of Harvard College.

- Doctoral Dissertation Fellowship (donated by the Institute for Scientific Information)

Kamala Balaraman, University of Hawaii, Interdisciplinary Doctoral Program in Communications and Information Science.

- K.G.SaurAwardforBest C\&RL Article

"The Electronic Revolution in Libraries: Microfilm Deja $V u^{\prime \prime}$ an article by Susan $A$. Cady appearing in the July 1990 issue of C\&RL.

- Miriam Dudley Bibliographic Instruction Librarian of the Year Carla Stoffle, university librarian, University of Arizona. standard indexing services (online and CD-ROM as well as print) to identify individuals, topics, and issues of concern to those seeking information on African Americans and others of African descent in periodical publications. This research 


\section{The Year in Review}

will document historical patterns and identify current trends which may need to be addressed in providing access to the periodical literature.

The Law and Political Science Section (LPSS)

Awards (cont.)

- The Katharine Kyes Leab and Daniel I. Leab American Book Prices Current Exhibition Catalogue Awards

Expensive:"Stephen Harvard: A Life in Letters," submitted by the Houghton Library, Harvard University

Moderate: "The Face of the Moon: Galileo to Apollo," entered by the Linda Hall Library, Kansas City, Missouri Inexpensive: "Fifteenth Century Italian Woodcuts from the Biblioteca Classense, Revenna," submitted by the Thomas Fisher Rare Book Library, University of Toronto Honorable Mention: "Encyclopedism from Pliny to Borges," from the University of Chicago's Special Collections (Division I); "Thomas Merton: The Poet and the Contemplative Life," entered by the Rare Book and Manuscript Library in the Butler Library, Columbia University, and Northwestern University Library's "Why Is This Night Different? Passover Haggadot from the Stephen P. Durchslag Collection"(Division II); "On the Edge of the War Zone: Women Writers and World War I," submitted by McFarlin Library's De-
(Marta Lange, chair) continued efforts to work closely with publishers of major law and political science indexes, reviewing those indexes and providing feedback to the publishers for improvements. The Section published its first such review of A Current Bibliography of African Affairs in the LPSS News.

The Slavic and East European Section (SEES) (Tanja Lorkovic, chair) Automation and Bibliographic Control Committee (Janet Crayne, chair) distributed a survey on remote access to Slavic collections. All collections listed in the most recent edition of International Directory of Librarians and Library Specialists in the Slavic and East European Field will be included in the findings.

The Racial and Ethnic Diversity Committee (Susana A. Hinojosa, chair) submitted a preliminary report on the survey of ACRL units identifying plans, activities, and programs relating to racial and ethnic diversity.

Fee-Based Information Service Centers in Academic Libraries Discussion Group (FISCAL) (Helen B. Josephine, chair) members gave testimony at the ALA Intellectual Freedom Committee hearings on fees for library services. 


\section{The Year in Review}

GoAL 3.

AdvocaCy AND Liaison.
Promote AND SPEAK FOR THE

INTERESTS OF ACADEMIC AND

RESEARCH LIBRARIANSHIP.

$1 \begin{aligned} & \text { he Bibliographic Instruction Section (BIS) (Betsy Wil- } \\ & \text { son, chair) with the Association for Library and Infor- } \\ & \text { mation Science Education sponsored a joint forum on }\end{aligned}$

library education for bibliographic instruction.

EBSS is represented on the Access ERIC board; they have begun reviewing information literacy wording in teacher accreditation standards; the Ad Hoc Legislation Committee has been involved in ACRL and ALA discussions on the NREN (National Research and Education Network).

The White House Conference on Library \& Information Services Task Force (WHCLIS) (Patricia A. Wand, chair) wrote a position paper, "Academic Libraries: A Source of National Strength," and continued a monthly column for CERL News.

The Professional Liaison Committee(Melvin R. George, chair) provided grants to six ACRL members to make presentations at the conferences of four other professional associations.

The Government Relations Committee (Hiram Davis, chair) inaugurated the Legislative Network this year in a joint effort with the Chapters Council (Vicki Montavon, chair).

The Law and Political Sciences Section (LPSS) established liaisons to ACRL WESS and the Special Libraries Association Social Sciences Division.

Some 23 Slavic and East European Section (SEES) members attended the International Slavic Librarians' Conference in Cambridge, England, and met with 113 colleagues from 18 countries.

The Task Force on Faculty Advisory Committee Orientation Material (Florence Doksansky, chair) published a final report, "Checklist for Development of Faculty Advisory Committee Orientation Materials" (CERL News, October 1991, p. 582).

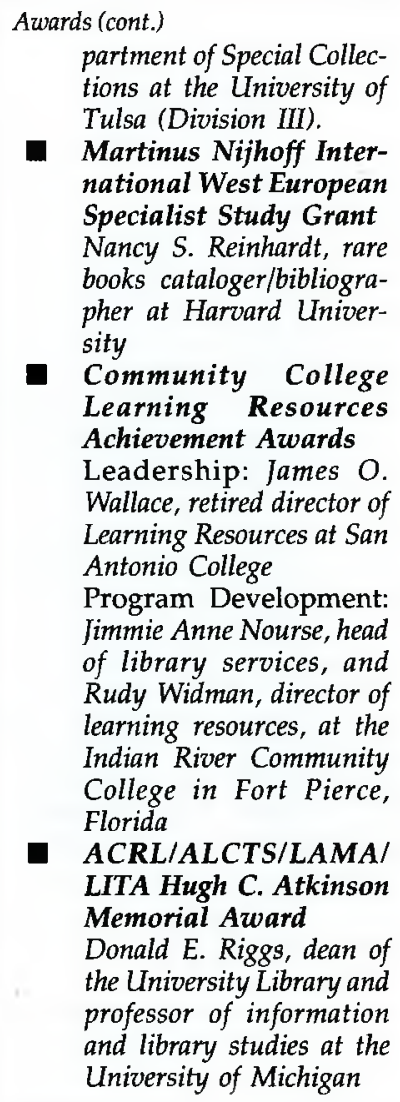
tions at the University of Tulsa (Division III).

a Martinus Nijhoff International West European Specialist Study Grant Nancy S. Reinhardt, rare books cataloger/bibliographer at Harvard University

- Community College Learning Resources Achievement Awards Leadership: James $O$. Wallace, retired director of Learning Resources at San Antonio College

Program Development: Jimmie Anne Nourse, head of library services, and Rudy Widman, director of learning resources, at the Indian River Community College in Fort Pierce, Florida

- ACRL/ALCTS/LAMA/ LITA Hugh C. Atkinson Memorial Award

Donald E. Riggs, dean of the University Library and professor of information and library studies at the University of Michigan 


\section{The Year in Review}

Goal 4.

Research \& Publication.
PROMOTE STUDY, RESEARCH, AND

PUBLICATION RELEVANT TO

ACADEMIC AND RESEARCH

LIBRARIANSHIP.

\section{7 he Audiovisual Committee (Richard N. Shaw, chair) published Audiovisual Policies in College Libraries in the College Libraries Section CLIPNotes series.}

The Australian Studies Discussion Group (Murray S. Martin, chair) has taken responsibility for Australia

ACRL Journals

- Choice

Book review journal of ACRL. Eleven issues per year (July/ August combined).

- College \& Research Libraries

Official journal of ACRL. Six bimonthly issues per year.

- College \& Research $\mathrm{Li}$ braries News Official news magazine of ACRL. Eleven issues per year (July/ August combined).

- Rare Books and Manuscripts Librarianship A journal of theory and practice covering all aspects of special collections librarianship. Two issues per year. and New Zealand in the joint ACRL/MLA bibliography project.

The FISCAL Directory of Fee-Based Information Services in Libraries was compiled and published.

The Task Force on Alternative Sources of Revenue in Academic Libraries (Anne Beaubien, chair) published a survey report, "Alternative Sources of Revenue for Academic Libraries," with the ALA Office of Research. The H. W. Wilson Foundation funded this study. (See CERL News, October 1991, pp. 573-576.)

Rare Books \& Manuscripts Librarianship (Alice Schreyer, editor) will be indexed in Library Literature and the MLA International Bibliography beginning with issues bearing the 1991 imprint date.

The New Publications Advisory Committee (DamarisSchmitt, chair) published two brochures connected to the information literacy theme: "Information Literacy: Critical Skills for a Changing World," and "Evaluating Information: A Basic Checklist." The Committee also selected two individuals-John F. Kennedy and Zora Neal Hurston-and inspirational quotations from their writings to be represented in the Great Minds poster series published by ALA Graphics.

College and Research Libraries (CERL) (Gloriana St. Clair, editor) has increased the number of articles by and about minority librarians, college librarians, and college libraries. 


\section{The Year in Review}

\section{Choice}

The year was one of transition and scaledown for Choice. Files were designed for the reveiws database and the reviewer profiles in the STAR publishing system. The pilot project making Choice reviews available online through site licenses with CARL and Carnegie-Mellon has been well received and a panel discussion on this project was held at ALA's Annual Conference in Atlanta.

Subscription fulfillment for the magazine and the reviews on cards was transferred to ALA's Subscriptions Department; Choice staff was reduced by one.

The Choice Advertising Department assumed responsibility for selling space advertising for six of ALA's divison journals in addition to the selling responsibilities they already have for Choice, Booklist, and Booklinks.

The supplement to the 10th edition of the Guide to Reference Books neared completion. Approximately $85 \%$ of the planned 4,500 annotated entries were received, edited, and entered into the Guide database. Publication is planned for the ACRL National Conference; electronic products will be available.

Planning for the next edition of Books for College Libraries began. The Choice Editorial Board increased by two members and assumed editorial oversight for the publication.

The Choice Editorial Board (Connie K. McCarthy, chair) approved publication of the WESS annual list of recommended foreign language titles in Choice.

\section{New Titles from ACRL in 1991}

- ACRL/Historically Black Colleges \& Universities Library Statistics, 1988-89, compiled by Robert $E$. Molyneux

- Audiovisual Policies in College Libraries (Clip Note 14), compiled by Kristine Brancolini

- Genre Terms: A Thesaurus for Use in Rare Book and Special Collections Cataloguing (2nd ed.) prepared by the Bibliographic Standards Committee of the Rare Books and Manuscripts Section

- Read This First: An Owner's Guide to the New Model Statement of Objectives for Academic Bibliographic Instruction, Carolyn Dusenbury. Monica Fusich, Kathleen Kenny, Beth Woodard, eds.

a Recruiting the Academic Library Director, Ruth J. Person and Sharon J. Rogers. Offered as a companion to The Search Committee Handbook: A Guide to Recruiting Administrators (AAHE)

- College \& Research Libraries and College \& Research Libraries News, Index for Volumes 41-50 (1980-1989), compiled by Eldon W. Tamblyn 


\section{ACRL Board of Directors, 1990-91}

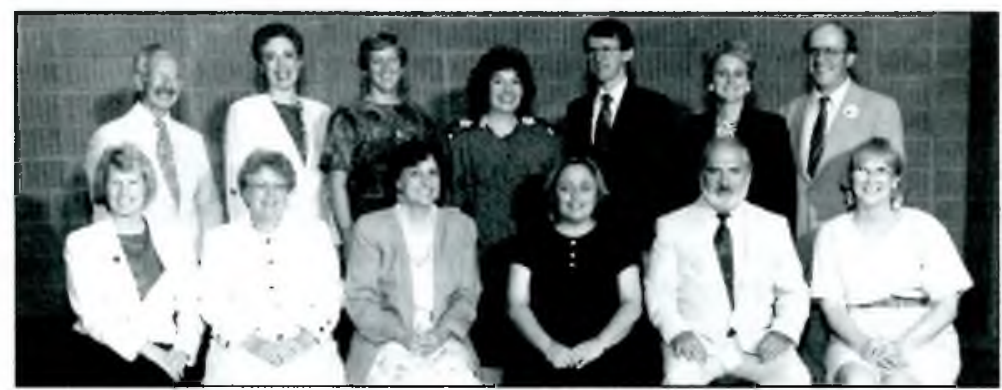

Back row: Evan Ira Farber, Cathleen Bourdon, Shelley E. Phipps, Rochelle Sager, Larry L. Hardesty, Barbara J. Wittkopf, Peter P. Malanchuk. Front row: Leslie A. Manning, Eileen Dubin, Anne K. Beaubien, Barbara J. Ford, William A. Moffett, Karin E. Begg.

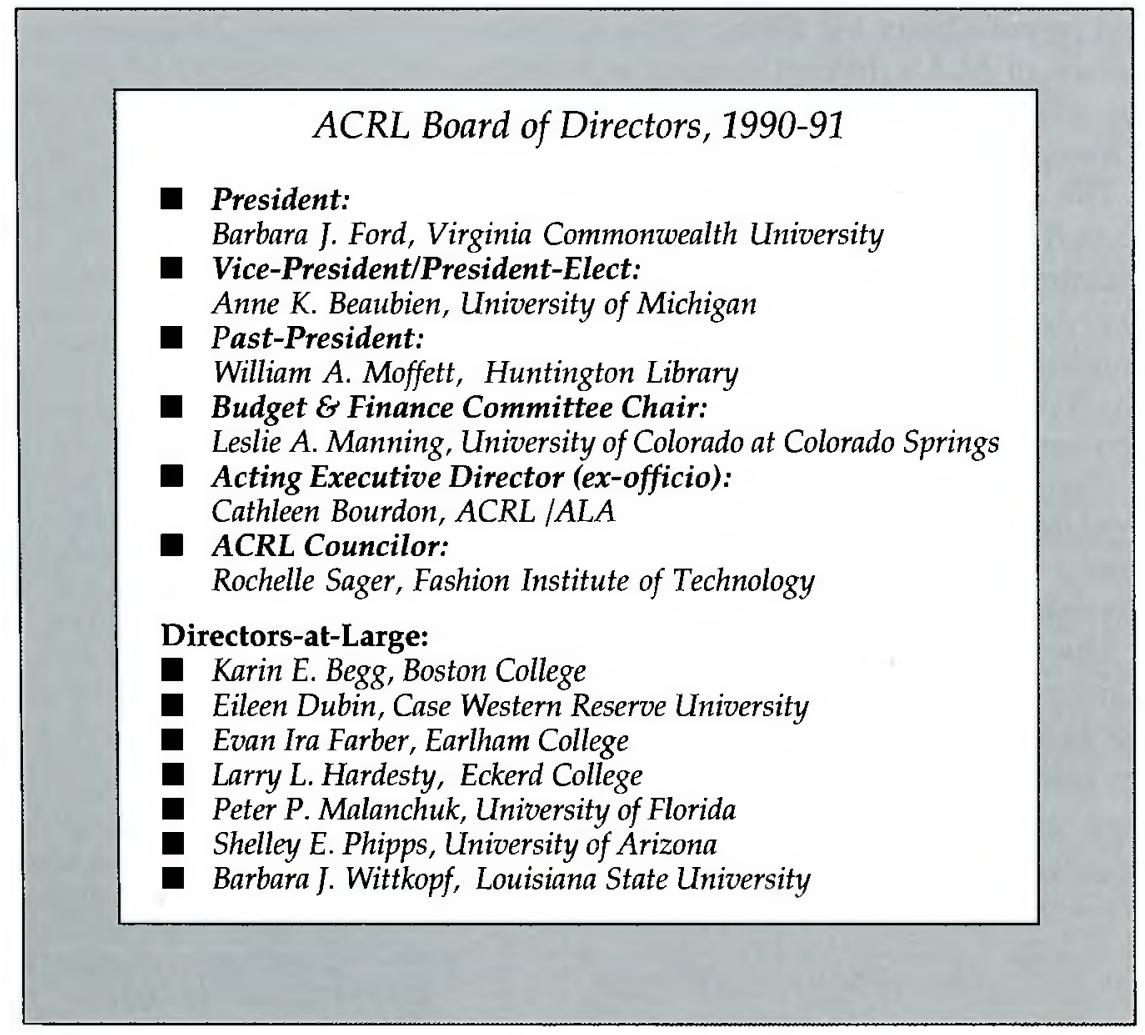




\section{Financial Report}

\section{Leslie A. Manning \\ Budget and Finance Committee Chair}

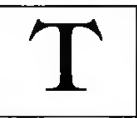

he 1991 fiscal year ended with a slightly larger deficit than we planned. Of the $\$ 102,101$ deficit, nearly $\$ 64,000$ was for expenses for the ACRL Sixth National Confer-

ence in Salt Lake City. We expect to recover the full amount when we receive the conference registration and exhibit fees. The remainder of the deficit was for the continuing education programs and CERL News.

Despite the larger than expected deficit, ACRL's financial position remains strong. ACRL maintains a reserve equal to 40 percent of the average expenditures from the past three years. At the end of this fiscal year our "Operating Fund Balance" stood at $\$ 414,485$. This is just slightly under our mandated reserve of $\$ 421,000$.

ACRL currently administers three award endowments: Hugh Atkinson Memorial, Oberly, and the Leab. At the end of this fiscal year the three endowments totaled $\$ 80,275$. The ACRL Board of

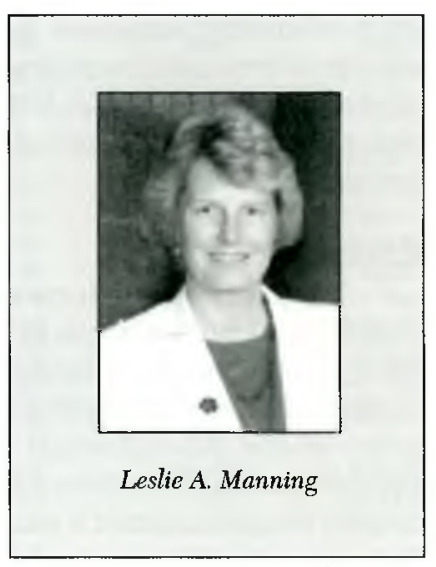
Directors voted this year to establish two new endowments: one to support ACRL programs and the other to support Choice activities. The ALA Executive Board will vote this fall on our request to establish the endowments. Interest earned on endowments is retained by ACRL, where as interest earned on our $\$ 400,000$ plus reserve is returned to ALA.

The accompanying table shows our revenue and expenses in four major categories: Membership Dues/Services, Publications, Educational Programs, and Funded Projects.

\section{Membership Dues/Services}

Revenue from dues was only slightly below the budget level. Not only has the number of personal members remained steady, the number of organizational members increased slightly. The money from your dues goes to support all of the programs listed under "Membership activities" on the expense side of the table. Although we only received $\$ 357,493$ from dues, we spent $\$ 407,878$ on membership services. Much of the difference was 


\section{Financial Report}

needed for C\&RL News. Our revenue from classified advertising in CERL News was down 30 percent. As academic libraries across the country were forced to freeze or eliminate positions, the number of classified ads, and subsequently our revenue, was reduced. We were able to use our reserve to cushion the loss this year.

\section{Publications}

Choice, the premier reviewing tool for academic libraries enjoyed another successful year. Although $C \mathcal{E} R L$ experienced a decline in product advertising (as did CERL News), it maintained its strong subscriber base. Although the revenue from book sales was right on target, the actual number of titles sold was less than last year.

\section{Education}

The continuing education courses ran in the red again as they have since they began in the early 1980s. At the advice of the Budget and Finance Committee, the ACRL Board of Directors voted to discontinue offering these continuing education courses prior to the ALA Annual Conference. Of the three other preconferences offered this year, the Rare Books and Manuscripts Section program earned a small surplus, while the Bibliographic Instruction Section program and the Historically Black College and University (HBCU) libraries program carried small losses.

\section{Funded projects}

The Mellon Foundation provided $\$ 16,500$ to collect statistics from HBCU libraries. The project will be completed in 1992.

I want to thank the members of the Budget and Finance Committee and Cathleen Bourdon for their many hours of dedicated service. Their efforts, together with staff expertise, have kept the association on solid financial ground. 


\section{Financial Report}

\section{EXECUTIVE SUMMARY 1990-1991}

\begin{tabular}{|c|c|c|c|c|}
\hline SOURCES OF REVENUE & $\begin{array}{r}\text { FY } 1991 \\
\text { BUDGET }\end{array}$ & $\begin{array}{l}\text { FY } 1991 \\
\text { ACTUAL }\end{array}$ & $\begin{array}{r}\text { PERCENT } \\
\text { OF BUDGET }\end{array}$ & $\begin{array}{l}\text { FY } 1990 \\
\text { ACTUAL }\end{array}$ \\
\hline Membership dues and other & $\$ 348,835$ & $\$ 351,172$ & $100.7 \%$ & $\$ 317,388$ \\
\hline Other & $\$ 500$ & $\$ 2,411$ & $482.2 \%$ & $\$ 2,987$ \\
\hline Advisory & $\$ 500$ & $\$ 0$ & $0.0 \%$ & $\$ 1,000$ \\
\hline Awards & $\$ 13,184$ & $\$ 650$ & $4.9 \%$ & $\$ 7,234$ \\
\hline Jobline & $\$ 3,300$ & $\$ 3,260$ & $98.8 \%$ & $\$ 3,349$ \\
\hline Subtotal & $\$ 366,319$ & $\$ 357,493$ & $97.6 \%$ & $\$ 331,958$ \\
\hline \multicolumn{5}{|l|}{ Publications } \\
\hline Choice & $\$ 1,579,161$ & $\$ 1,530,417$ & $96.9 \%$ & $\$ 1,501,475$ \\
\hline C\&RL & $\$ 128,780$ & $\$ 121,451$ & $94.3 \%$ & $\$ 136,620$ \\
\hline C\&RL News & $\$ 287,120$ & $\$ 223,323$ & $77.8 \%$ & $\$ 280,772$ \\
\hline RBML & $\$ 20,370$ & $\$ 18,330$ & $90.0 \%$ & $\$ 22,319$ \\
\hline FJLS & $\$ 0$ & $\$ 0$ & $0.0 \%$ & $\$ 3,530$ \\
\hline Sec. Newsletters & $\$ 60$ & $\$ 18$ & $30.0 \%$ & $\$ 82$ \\
\hline Nonperiodical Pubs. & $\$ 82,290$ & $\$ 82,320$ & $100.0 \%$ & $\$ 83,407$ \\
\hline $\mathrm{BCL}$ & $\$ 9,550$ & $\$ 12,375$ & $129.6 \%$ & $\$ 24,895$ \\
\hline Chapter Topics & $\$ 0$ & $\$ 0$ & & $\$ 0$ \\
\hline Subtotal & $\$ 2,107,331$ & $\$ 1,988,234$ & $94.3 \%$ & $\$ 2,053,100$ \\
\hline \multicolumn{5}{|l|}{ Education } \\
\hline Continuing Ed. & $\$ 16,550$ & $\$ 17,689$ & $106.9 \%$ & $\$ 25,891$ \\
\hline National $(89,92)$ & $\$ 0$ & $\$ 0$ & $0.0 \%$ & $(\$ 1,170)$ \\
\hline Pre-\& Posiconferences & $\$ 49,450$ & $\$ 51,405$ & $104.0 \%$ & $\$ 21,730$ \\
\hline CJCLS Teleconference & $\$ 0$ & $\$ 2,385$ & $0.0 \%$ & $\$ 0$ \\
\hline RBMS Cambridge, WESS & \$o & $\$ 0$ & $0.0 \%$ & $\$ 56,630$ \\
\hline Subtotal & $\$ 66,000$ & $\$ 71,479$ & $108.3 \%$ & $\$ 103,081$ \\
\hline \multicolumn{5}{|l|}{ Funded Projects } \\
\hline NEH Project A & $\$ 0$ & \$o & $0.0 \%$ & $\$ 0$ \\
\hline NEH/HBCU Project & $\$ 0$ & \$o & $0.0 \%$ & $\$ 154$ \\
\hline HBCU Statistics & $\$ 16,500$ & $\$ 9,179$ & $55.6 \%$ & $\$ 0$ \\
\hline Subiotal & $\$ 16,500$ & $\$ 9,179$ & $55.6 \%$ & $\$ 154$ \\
\hline TOTAL REVENUE & $\$ 2,556,150$ & $\$ 2,426,385$ & $94.9 \%$ & $\$ 2,488,293$ \\
\hline Choice Revenue & $\$ 1,579,161$ & $\$ 1,530,417$ & $96.9 \%$ & $\$ 1,501,475$ \\
\hline TOTAL REV. W/O CHOICE & $\$ 976,989$ & $\$ 895,968$ & $91.7 \%$ & $\$ 986,818$ \\
\hline
\end{tabular}




\section{Financial Report}

\begin{tabular}{|c|c|c|c|c|}
\hline OBJECT OF EXPENSE & $\begin{array}{r}\text { FY } 1991 \\
\text { BUDGET }\end{array}$ & $\begin{array}{l}\text { FY } 1991 \\
\text { ACTUAL }\end{array}$ & $\begin{array}{r}\text { PERCENT } \\
\text { BUDGET }\end{array}$ & $\begin{array}{l}\text { FY } 1990 \\
\text { ACTUAL }\end{array}$ \\
\hline \multicolumn{5}{|l|}{ Membership Activities } \\
\hline Membership Svcs. & $\$ 51,320$ & $\$ 40,433$ & $78.8 \%$ & $\$ 40,044$ \\
\hline Exec. Comm. \& Board & $\$ 51,390$ & $\$ 66,373$ & $129.2 \%$ & $\$ 77,300$ \\
\hline Statistics & $\$ 3,620$ & $\$ 3,191$ & $88.1 \%$ & $\$ 4,993$ \\
\hline Advisory & $\$ 37,440$ & $\$ 32,130$ & $85.8 \%$ & $\$ 27,352$ \\
\hline Standards distrib. & $\$ 5,830$ & $\$ 4,626$ & $79.3 \%$ & $\$ 5,989$ \\
\hline Discussion Groups & $\$ 4,570$ & $\$ 4,421$ & $96.7 \%$ & $\$ 6,699$ \\
\hline Awards & $\$ 30,581$ & $\$ 15,802$ & $51.7 \%$ & $\$ 13,523$ \\
\hline Chapters & $\$ 48,060$ & $\$ 41,314$ & $86.0 \%$ & $\$ 51,215$ \\
\hline Committees & $\$ 50,100$ & $\$ 50,685$ & $101.2 \%$ & $\$ 81,212$ \\
\hline Sections & $\$ 45,030$ & $\$ 43,490$ & $96.6 \%$ & $\$ 60,838$ \\
\hline Jobline & $\$ 4,940$ & $\$ 4,038$ & $81.7 \%$ & $\$ 2,352$ \\
\hline Section Newsletters & $\$ 32,660$ & $\$ 33,575$ & $102.8 \%$ & $\$ 33,281$ \\
\hline Chapter Topics & $\$ 4,760$ & $\$ 4,523$ & $95.0 \%$ & $\$ 2,290$ \\
\hline C\&RLNews subsidy & $\$ 0$ & $\$ 63,277$ & $0.0 \%$ & $\$ 0$ \\
\hline Sublotal & $\$ 370,301$ & $\$ 407,878$ & $110.1 \%$ & $\$ 407,088$ \\
\hline \multicolumn{5}{|l|}{ Special Projects, Internal Funding } \\
\hline Output Measures & $\$ 2,350$ & $\$ 1,855$ & $78.9 \%$ & $\$ 15,858$ \\
\hline Special Grants Fund & $\$ 14,550$ & $\$ 11,138$ & $76.5 \%$ & $\$ 6,977$ \\
\hline Subtotal & $\$ 16,900$ & $\$ 12,993$ & $76.9 \%$ & $\$ 22,835$ \\
\hline \multicolumn{5}{|l|}{ Publications } \\
\hline Choice & $\$ 1,641,461$ & $\$ 1,559,766$ & $95.0 \%$ & $\$ 1,408,416$ \\
\hline C\&RL & $\$ 130,250$ & $\$ 112,751$ & $86.6 \%$ & $\$ 108,045$ \\
\hline C\&RL News & $\$ 292,380$ & $\$ 223,323$ & $76.4 \%$ & $\$ 259,962$ \\
\hline RBML & $\$ 20,580$ & $\$ 23,672$ & $115.0 \%$ & $\$ 11,272$ \\
\hline FJLS & $\$ 0$ & $\$ 0$ & $0.0 \%$ & $\$ 6,329$ \\
\hline Nonperiodical Pubs. & $\$ 48,690$ & $\$ 39,024$ & $80.1 \%$ & $\$ 40,208$ \\
\hline $\mathrm{BCL}$ & $\$ 2,930$ & $\$ 2,955$ & $100.9 \%$ & $\$ 982$ \\
\hline Subtotal & $\$ 2,136,291$ & $\$ 1,961,491$ & $91.8 \%$ & $\$ 1,835,214$ \\
\hline \multicolumn{5}{|l|}{ Education } \\
\hline Continuing Ed. & $\$ 51,830$ & $\$ 49,955$ & $96.4 \%$ & $\$ 75,984$ \\
\hline National $(89,92)$ & $\$ 55,160$ & $\$ 63,584$ & $115.3 \%$ & $\$ 15,991$ \\
\hline Pre-\& PostConferences & $\$ 47,340$ & $\$ 52,237$ & $110.3 \%$ & $\$ 35,291$ \\
\hline CJCLS Teleconference & $\$ 0$ & $\$ 0$ & $0.0 \%$ & $\$ 0$ \\
\hline RBMS Cambridge, WESS & $\$ 0$ & $\$ 0$ & $0.0 \%$ & $\$ 46,627$ \\
\hline Subtotal & $\$ 154,330$ & $\$ 165,776$ & $107.4 \%$ & $\$ 173,893$ \\
\hline \multicolumn{5}{|l|}{ Funded Projects } \\
\hline NEH Project A & $\$ 0$ & $\$ 0$ & $0.0 \%$ & $\$ 0$ \\
\hline NEH/HBCU Project & $\$ 0$ & $\$ 0$ & $0.0 \%$ & $\$ 154$ \\
\hline HBCU Statistics & $\$ 19,960$ & $\$ 9,697$ & $48.6 \%$ & $\$ 0$ \\
\hline Subtotal & $\$ 19,960$ & $\$ 9,697$ & $48.6 \%$ & $\$ 154$ \\
\hline TOTAL EXPENSES & $\$ 2,697,782$ & $\$ 2,557,835$ & $94.8 \%$ & $\$ 2,439,184$ \\
\hline Choice Expenses & $\$ 1,641,461$ & $\$ 1,559,766$ & $95.0 \%$ & $\$ 1,408,416$ \\
\hline TOTAL EXP. W/O CHOICE & $\$ 1,056,321$ & $\$ 998,069$ & $94.5 \%$ & $\$ 1,030,768$ \\
\hline NET & $(\$ 79,332)$ & $(\$ 102,101)$ & & $(\$ 43,950)$ \\
\hline Operating fund balance & $\$ 516,479$ & $\$ 516,586$ & & \\
\hline 1991 net & & $(\$ 102,101)$ & & \\
\hline Ending fund balance & & $\$ 414,485$ & & \\
\hline Endowment fund balance & $\$ 67,783$ & $\$ 67,783$ & & \\
\hline 1991 net & & $\$ 12,492$ & & \\
\hline Ending fund balance & & $\$ 80,275$ & & \\
\hline
\end{tabular}

